\title{
移動する物体に対する適応制御を用いた力制御
}

\author{
山田 祐士 $^{* 1}$, 高津 康幸 ${ }^{* 2}$, 野村 高広 ${ }^{* 1}$, 則次 俊郎 ${ }^{* 3}$
}

\section{Force control of moving object using adaptive control}

\author{
Yuji YAMADA ${ }^{* 1}$, Yasuyuki TAKATSU ${ }^{* 2}$, Takahiro NOMURA*1 and Toshiro NORITSUGU*3 \\ ${ }^{* 1,{ }^{*}}$ Dept. of Mechanical Engineering, Kure National College of Technology, \\ 2-2-11 Agaminami, Kure-shi, Hiroshima 737-8506 Japan \\ ${ }^{*}$ Tsuyama National College of Technology, \\ 624-1 Numa, Tsuyama-shi, Okayama 708-8509, Japan
}

\section{Received 25 March 2014}

\begin{abstract}
A pneumatic servo seems to be effectively applied to many varieties of gripping or compressing works, because its high compressibility is useful to the force control. In the force control system, the characteristic of the object is comprised in the closed loop, so its influence has to be considered in the design of controller. However, it is generally unknown and often changes during operation. In particular, the characteristics of the plant changes significantly, when the object is moving. To cope with these problems, more intelligent control schemes are required. In this paper, we propose a design scheme of a model reference adaptive control with Neural Network for a force control system with pneumatic servo. The effectiveness of the proposed design scheme is confirmed by experiments using the existent pneumatic servo system.
\end{abstract}

Key words: Pneumatic servo system, Adaptive control, Neural network, Moving object, MRAC

\section{1. 緒言}

空気圧シリンダは，空気圧を駆動源とすることから取り扱いが容易な上，圧力に比例した力が簡単に得られる 一方で空気の圧縮性により高精度な制御を苦手としている。しかし，空気の圧縮性に起因する低剛性という特徵 は，衝撃力の緩和や反力の吸収などの利点を有し，力制御に適していると考えられる．特に低圧で駆動される空 気圧系はパッシブコンプライアンスという特性を求められる他の機械や人との協調作業や微細な力制御を必要と する接触作業への応用が期待されている. このような期待にこたえるためには，空気圧サ一ボ系の制御性能を向 上して低圧で駆動する空気圧シリンダを用いた微細な力制御に応用することが有効であると考えられる。

空気圧サーボ系の制御性能を向上させるための本格的な制御理論の適用は，最適制御などの制御理論が最初に 応用されるようになった(山藤他, 1987, 則次他, 1988a). 制御対象の挙動が線形モデルによって正確に記述され, そのパラメータが動作中に大きく変化しなければ，これらの制御手法は有効であるが，実際には空気圧サ一ボ系 の制御性能を劣化させる原因の一つとなる空気の圧縮性に起因する圧力応答の遅れや摺動部の摩擦の変動などに よる特性変動が存在する。そこで空気の圧縮性や負荷質量の違いによるプラントの特性変動に対応するため適応 制御の応用が試みられるようになった(則次他, 1988b，則次他，1990，坂田他,1993，内山他，2003)。しかし，これ らの研究の多くは，空気圧サーボ系の位置制御を扱っており，特に移動する物体に対する力制御はほとんど行わ れていない，また，空気圧サーボ系は，空気の圧縮性，制御弁やシリンダ，ピストンなどの摩擦といった非線形 要素を本質的に含む系でもある。これらのプラントに与える影響が小さい場合には，適応制御手法のみでも満足 のいく制御性能が達成されているが，非線形性の影響が大きい場合には非線形性を補償する制御手法が必要とな る. 一方，ニューラルネットワーク(以下， NN と呼ぶ)のもつ柔軟性，非線形写像能力に着目し，NNを非線形な

No.14-00169 [DOI: 10.1299/transjsme.2014dr0266]

*1 正員，吳工業高等専門学校 機械工学科（†737-8506 広島県只市阿賀南 2-2-11）

*2 正員，吳工業高等専門学校 機械工学科（現 福岡工業大学 工学部)

*3 正員，フェロー，津山工業高等専門学校（一708-8509 岡山県津山市沼 624-1）

E-mail of corresponding author: yamada@kure-nct.ac.jp 
制御対象一応用寸る研究が行われている(辻他, 1994). しかし, 実際の機器への応用を考えた場合, NN の学習に MRAC 内で用いられる信号を利用しているため，併用する MRAC に対して外乱等の対策が必要となる，すなわ ち, 外乱に対する対策のない状態で実機応用を行った場合には, 実在する摩擦等の外乱により MRAC の制御性能 が劣化するだけにとどまらず，NN も十分に働かないことも考えられる，そこで，本論文では，内部信号を改善 した MRAC に対してNN の併用を行った構成法を示し, 移動する物体に対する空気圧を応用した力制御系の提案 を行う. 本構成法では, 内部信号の改善により MRAC 自身の制御性能を高めるだけでなく, NN の学習性能を向 上させる構成法を用いた. 寸なわち, NNにおいても MRAC 内の信号が一部に用いられているため, MRAC 内に おいて実際に存在する外乱を考慮した構成法を用いることでNNを併用した MRAC 全体の改善を行った.最後に, 本構成法の有用性を確認するために, 本論文で提案する構成法を空気圧サーボ系に適用して行った実験結果につ いても示す.

\section{2. 空気圧サーボ系の構成}

本章では, 本研究で対象とする空気圧サーボ系の構成を示し, この空気圧サーボ系のモデル化を行う.

\section{$2 \cdot 1$ システムの構成}

図 1 に本研究で用いる力センサを含む空気圧系の構成を示寸.シリンダは内径 $9.3 \mathrm{~mm}$ ，ストローク $75 \mathrm{~mm}$ で, ロッド径 $3 \mathrm{~mm}$ の両ロッド形複動低摩擦シリンダ（Airpot 社製 Airpel）を用いた．ピストンロッドの先端には水平 方向に移動する台車が取り付けてある. 台車の移動量の検出にはリニアエンコーダ (SONY 社製マグネスケール) を用いた，台車の先にはカセンサ（NITTA 社製 PD3）が取り付けてある. その前方には移動する物体が設置して あり，シリンダの伸縮方向に移動することが出来る，その物体とカセンサとの間には，ばねが設置され，力セン サを保護すると同時に，このばねの硬さを台車と物体間の硬さと考えた. 物体の移動は，モータとリンク機構に より制御され，シリンダから加わる力とは関係なく動作される. 寸なわち, シリンダが力を及ぼす物体はシリン ダと同軸方向に移動するが，その位置は不明であり，力センサからの情報により物体間の力制御が行われること になる. また, 制御弁は 2 個の 3 方向電空比例圧力制御弁（SMC 社製 ITV）を用いている. 制御弁の一次側一 の供給圧力 $\mathrm{P}_{\mathrm{S}}$ は $0.5 \mathrm{MPa}$ とし, 二次側圧力 $\mathrm{P}_{1}$ および $\mathrm{P}_{2}$ はピストンの平衡時に $0.3 \mathrm{MPa}$ に設定した.

つぎに制御信号の流れについて示す. シリンダの移動量の検出は前述のリニアエンコーダからの信号をディテ クタで移動量に対応したパルス信号に変換し， 24 ビットアップダウンカウンタモジュールで台車が物体に近づく 方向がプラスとなるようにカウントされディジタル信号として計算機に入力される. 計算機上での位置検出の分 解能は $1 \mu \mathrm{m}$ である. 制御弁の制御信号は 12 ビットのディジタル信号として計算機から 2 個の D/A コンバータ 一出力される.この制御信号は D/A 変換されてアナログ量となり, 制御弁に電圧信号として送られる. 制御弁で は送られてきた信号に比例した圧力が発生し，その力で空気圧シリンダを駆動する．また，接触力は力センサか らアナログ信号を $\mathrm{A} / \mathrm{D}$ コンバータでディジタル信号に変換し計算機に入力される.

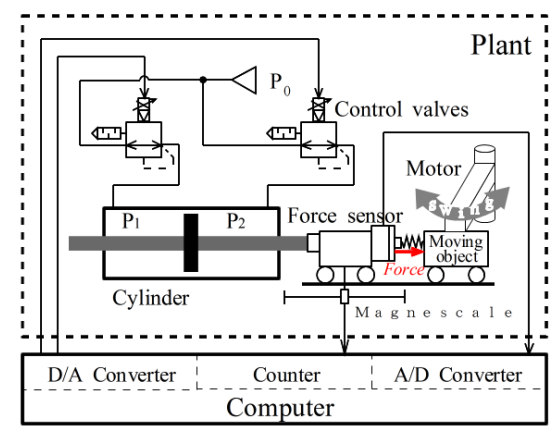

(a) Schematic view of the pneumatic system.

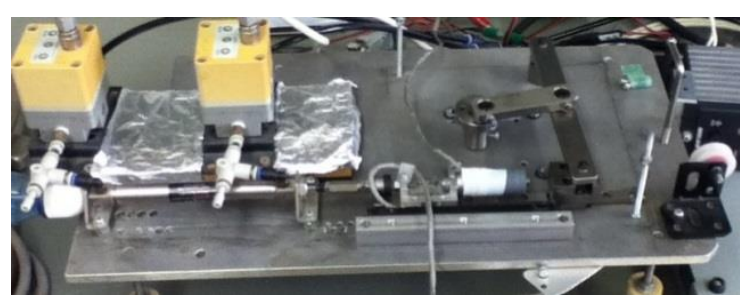

(b)Photo of the pneumatic system.

Fig.1 Schematic diagram of the pneumatic system. This system has the characteristics of the plant changes significantly, when the object is moving. 


\section{$2 \cdot 2$ 制御対象のモデル}

本研究では低圧で駆動する空気圧サーボ系に対する適応制御系の構成法を提案する．ピストンおよび物体の移 動に伴い発生する摩擦力などの力を外乱として最初は無視する. したがって, ピストン位置を $x[\mathrm{~m}]$, シリンダ内 の圧力差を $p[\mathrm{~Pa}]$ とすると，つぎのような運動方程式が成り立つ.

$$
A p=M \ddot{x}+D \dot{x}+K x
$$

ただし,

$$
\begin{aligned}
& A: \text { ピストン受圧面積 }\left[\mathrm{m}^{2}\right] \\
& M: \text { 負荷質量 }[\mathrm{kg}] \\
& D: \text { 粘性摩擦係数 }[\mathrm{N} \cdot \mathrm{sec} / \mathrm{m}] \\
& K: \text { ばね定数 }[\mathrm{N} / \mathrm{m}]
\end{aligned}
$$

式(1)のラプラス変換をとると

$$
A P(s)=\left\{M s^{2}+D s+K\right\} X(s)
$$

したがって，シリンダ内圧力とピストン位置の関係は次式で表される.

$$
\frac{X(s)}{P(s)}=\frac{A}{M s^{2}+D s+K}
$$

図 2 にパワーアンプヘステップ状の入力電圧を加えたときのシリンダ内の圧力応答（実線）を示す．これはシ リンダを一端に固定し入力電圧を $0[\mathrm{~V}]$ から $1.2[\mathrm{~V}]$ （すなわち， 2 次側圧力を $0.0[\mathrm{MPa}$ から 0.12[MPa]）に変化さ せた時のシリンダ内の圧力応答を測定したものである. この図より, 印加電圧とシリンダ内圧力の関係をむだ時 間の含まれる 1 次遅れ系（破線）で近似する. 寸なわち, 印加電圧 $u[\mathrm{~V}]$ とシリンダ内圧力 $p[\mathrm{~Pa}]$ の関係は次式で 表される.

$$
\frac{P(s)}{U(s)}=\frac{\alpha e^{-L v s}}{1+\mu s}
$$

ただし，

$\alpha:$ 変換ゲイン

$\mu:$ 時定数 $[\mathrm{sec}]$

$L_{v}:$ バルブのむだ時間[sec]

また, 物体が静止した状態においてはピストン位置 $\mathrm{x}[\mathrm{m}]$ とピストンロッド先端から生じる力 $\mathrm{y}[\mathrm{N}]$ の関係は次式 で表される.

$$
Y(s)=K X(s)
$$

したがって, パワーアンプヘの印加電圧を入力とし, シリンダの生じる力を出力としたときのプラントの伝達 関数はつぎのようになる

$$
\begin{aligned}
G(s) & =\frac{Y(s)}{U(s)}=\frac{Y(s)}{X(s)} \frac{X(s)}{P(s)} \frac{P(s)}{U(s)} \\
& =\frac{A K \alpha e^{-L_{v} s}}{\left(M s^{2}+D s+K\right)(1+\mu s)}
\end{aligned}
$$

ここで, 計算機の計算速度や計測機器の遅れ, 配管内での遅延など, バルブ以外の遅れ時間 $L_{p}$ を考慮するとシ ステム全体の伝達関数はつぎのようになる.

$$
G(s)=\frac{A K \alpha e^{-\left(L_{v}+L_{p}\right) s}}{\left(M s^{2}+D s+K\right)(1+\mu s)}
$$


一般に, 計測器自身にも遅れが存在するためシステムのむだ時間 $L\left(=L_{v}+L_{p}\right)$ を正確に求めることは難しいと されている. ここでは, システムの安全性を考慮して, バルブ以外の遅れ時間 $L_{p}$ に少し余裕をとりバルブの遅れ 時間と等しく $25[\mathrm{msec}]$ と仮定して離散化を行うこととした．すなわち，制御系全体のむだ時間 $L$ を $0.05[\mathrm{sec}$ とし て，式(7)のプラントをサンプリング周期 $\mathrm{T}(=L)$ で離散化するとつぎのような離散化モデルが得られる.

$$
A\left(z^{-1}\right) y(k)=z^{-2} B\left(z^{-1}\right) u(k)
$$

ただし，

$$
\left.\begin{array}{l}
A\left(z^{-1}\right)=1+a_{1} z^{-1}+a_{2} z^{-2}+a_{3} z^{-3} \\
B\left(z^{-1}\right)=b_{0}+b_{1} z^{-1}+b_{2} z^{-2}
\end{array}\right\}
$$

また, $u(k)$ と $y(k)$ はそれぞれプラントに加える入力電圧とシステムから出力される力となる.

ここで, 物体の移動に伴う摩擦力などの外力を一定值であると仮定すると, プラントモデルは式(8)に対応して 次式のようになる.

$$
A\left(z^{-1}\right) y(k)=z^{-2} B\left(z^{-1}\right) u(k)+w(k)
$$

ただし，

$$
w(k)=\text { const }
$$

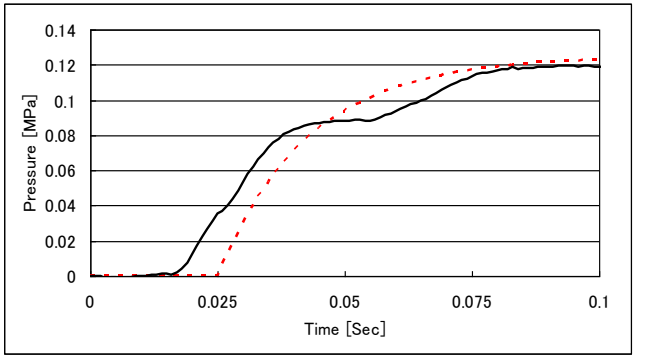

Fig. 2 Pressure response in the cylinder. The lag of the system is approximated by dead time $(=0.025 \mathrm{Sec})$ and time constant of a primary delay system.

\section{3. 線形化プラントに対する改善型モデル規範型適応制御の構成}

本章では，ニューラルネットワーク（NN）と併用を行う外乱を考慮した構成によるモデル規範形適応制御 （MRAC）の構成法について示す. 式(10)のプラント表現に対応して，つぎのような規範モデルを考える.

$$
y_{M}(k)=\frac{z^{-2} B_{M}\left(z^{-1}\right)}{A_{M}\left(z^{-1}\right)} r(k)
$$

ただし，

$$
\left.\begin{array}{l}
A_{M}\left(z^{-1}\right)=1+a_{M 1} z^{-1}+a_{M 2} z^{-2} \\
B_{M}\left(z^{-1}\right)=b_{M 0}+b_{M 1} z^{-1}
\end{array}\right\}
$$

ここで, $r(k)$ は有界な規範入力であり， $A_{M}\left(z^{-1}\right)$ は漸近安定多項式を示している．モデル規範型適応制御の制 御目的は, プラントの出力 $y(k)$ が規範モデルの出力 $y_{M}(k)$ に漸近的に追従するように制御入力 $u(k)$ を適応的に合成

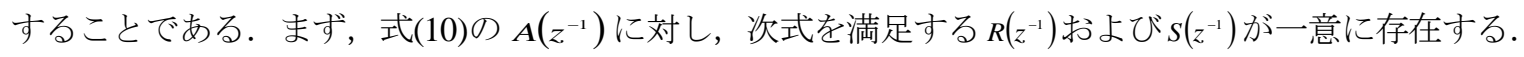

$$
A_{M}\left(z^{-1}\right)=A\left(z^{-1}\right) R\left(z^{-1}\right)+z^{-2} S\left(z^{-1}\right)
$$


ただし，

$$
\left.\begin{array}{l}
R\left(z^{-1}\right)=\left(1+r_{1} z^{-1}\right) D\left(z^{-1}\right) \\
S\left(z^{-1}\right)=s_{0}+s_{1} z^{-1}+s_{2} z^{-2}+s_{3} z^{-3}
\end{array}\right\}
$$

式(14)の両辺に $y(k+2)$ をかけ，式(10)に代入すると，次式が得られる.

$$
A_{M}\left(z^{-1}\right) y(k+2)=B\left(z^{-1}\right) R\left(z^{-1}\right) u(k)+S\left(z^{-1}\right) y(k)+R\left(z^{-1}\right) w(k)
$$

上式の右辺には一定值外乱に起因する $R\left(z^{-1}\right) w(k)$ なる項が現れるが，式(15)(16)より，

$$
R\left(z^{-1}\right) w(k)=\left(1-r_{1} z^{-1}\right)\left(1-z^{-1}\right) w(k)
$$

と表されるが，式(11)より $w(k)$ は一定值と仮定しているため，右辺の $\left(1-z^{-1}\right) w(k)$ は常に 0 となることから，

$$
R\left(z^{-1}\right) w(k) \equiv 0
$$

となり，外乱の影響は除去される.

式(17)の $y(k+2)$ を $y_{M}(k+2)$ で置き換えると, 制御入力 $u(k)$ は，つぎのように表わされる.

$$
B\left(z^{-1}\right) R\left(z^{-1}\right) u(k)=A_{M}\left(z^{-1}\right) y_{M}(k+2)-S\left(z^{-1}\right) y(k)
$$

ところで，実際にはプラントのパラメータは未知であるのでプラントの未知パラメータの同定を行い，その推 定值を用いてコントローラパラメータを決定していく必要がある.そこで，次にプラントパラメータの同定法に ついて述べる．まず，(10)式のプラント表現をつぎのように書き改める.

$$
y(k)=\theta^{T} \xi(k)+w(k)
$$

ただし，

$$
\theta=\left[a_{1}, a_{2}, a_{3}, b_{0}, b_{1}, b_{2}\right]^{T}
$$

$$
\xi(k)=[-y(k-1),-y(k-2),-y(k-3), u(k-2), u(k-3), u(k-4)]^{T}
$$

プラントに外乱の加わるような状況下においては外乱の影響を除去する必要があるので，パラメータ同定にお いても式(16)の外乱補償器を導入する.

式(21)の両辺に式(16)の $D\left(z^{-1}\right)$ を作用させると，

$$
y_{D}(k)=\theta^{T} \xi_{D}(k)+w_{D}(k)
$$

ただし，

$$
\left.\begin{array}{l}
y_{D}(k)=D\left(z^{-1}\right) y(k)=y(k)-y(k-1) \\
\xi_{D}(k)=D\left(z^{-1}\right) \xi(k)=\xi(k)-\xi(k-1) \\
w_{D}(k)=D\left(z^{-1}\right) w(k) \equiv 0
\end{array}\right\}
$$

となり外乱の影響が除去される。すなわち，ここで想定している一定值外乱のように，外乱が特定できれば， ここで用いている同定器を用いることにより，プラントパラメータの推定值は真值に収束されるような設計がな されている。したがって，式(24)に対応して同定モデルをつぎのように構成する。

$$
\hat{y}(k)=\hat{\theta}^{T}(k) \xi_{D}(k)
$$

ただし，

$$
\hat{\theta}(k)=\left[\hat{a}_{1}(k), \hat{a}_{2}(k), \hat{a}_{3}(k), \hat{b}_{0}(k), \hat{b}_{1}(k), \hat{b}_{2}(k)\right]^{T}
$$

同定誤差 $\varepsilon(k)$ を 


$$
\varepsilon(k)=\hat{y}_{D}(k)-y_{D}(k)=\hat{\theta}(k) \xi_{D}{ }^{T}(k)-y_{D}(k)
$$

と定義すれば， $\hat{\theta}(k)$ はつぎの固定トレースアルゴリズムを用いて同定することができる.

$$
\begin{aligned}
& \hat{\theta}(k)=\hat{\theta}(k-1)-\Gamma(k-1) \xi_{D}(k) \varepsilon^{\prime}(k) \\
& \varepsilon(k)=\frac{\hat{\theta}^{T}(k-1) \xi_{D}(k)-y_{D}(k)}{1+\xi_{D}{ }^{T}(k) \Gamma(k-1) \xi_{D}(k)} \\
& \Gamma(k)=\frac{1}{\lambda(k)}\left[\Gamma(k-1)-\frac{\Gamma(k-1) \xi_{D}(k) \xi_{D}{ }^{T}(k) \Gamma(k-1)}{1+\xi_{D}{ }^{T}(k) \Gamma(k-1) \xi_{D}(k)}\right] \\
& \lambda(k)=1-\frac{\left\|\Gamma(k-1) \xi_{D}(k)\right\|^{2}}{1+\xi_{D}{ }^{T}(k) \Gamma(k-1) \xi_{D}(k)} \cdot \frac{1}{t r \Gamma(0)} \\
& \varepsilon^{\prime}(k)= \begin{cases}\varepsilon(k)-\delta & \text {;if } \varepsilon(k)>\delta \\
0 & \text { if }|\varepsilon(k)| \leq \delta \quad, \quad, \delta>0 \\
\varepsilon(k)+\delta & \text { if } \varepsilon(k)<-\delta\end{cases} \\
& \text { ただし， } \\
& \Gamma(0)=\Gamma^{T}(0)>0
\end{aligned}
$$

\section{4.ＮN を併用したモデル規範型適応制御の構成}

ところで，実在の空気圧サーボ系では，空気の圧縮性や各種摩擦の影響でプラントは式(8)のような線形系では なく, 次のように非線形な関数 $f(\bullet)$ を用いて表現される非線形系となっていると考えられる.

$$
y(k)=f(v(k-2), v(k-3), v(k-4), y(k-1), y(k-2), y(k-3))
$$

ここで, $v(k), y(k)$ は，それぞれ合成入力およびプラント出力を表す. 今, 時刻 $\mathrm{k}-2$ を基準として $y(k-2), y(k-1)$ を順次消去すると，次のような非線形な関数 $g(\bullet)$ を用いて表現できる.

$$
y(k)=g(v(k-2), v(k-3), v(k-4), y(k-3), y(k-4), y(k-5))
$$

ここで, $y(k)$ と $v(k-2)$ の間に 1 対 1 対応を仮定し, $g(\bullet)$ の逆関数 $h(\bullet)$ を用いると, プラントの入力表現形式は つぎのように表される(辻他, 1994).

$$
v(k-2)=h(y(k), v(k-3), v(k-4), y(k-3), y(k-4), y(k-5))
$$

ここでは，上式の非線形プラントにNNを適用することにより，式(8)の線形プラントを導出し，これに対して MRAC を構成する方法を示す，まず，図 3 においてプラントの線形化にNNを組み込んだ MRAC の構成図を示 す. 図 3 において, NN と非線形プラントを組み合わせた点線で囲まれた部分が式(8)で表す線形プラントとなる ようにNNの重みを調整するものとする. また, 制御入力 $v(k)$ はMR ACの出力 $u(k)$ と NNの出力 $u_{N}(k)$ の和

$$
v(k)=u(k)+u_{N}(k)
$$

で合成される. 式(37)よりプラント出力 $y(k)$ を規範モデルの出力 $y_{M}(k)$ に追従させる制御入力 $u(k)$ は次式で与えら れる.

$$
u(k)=h\left(y_{M}(k+2), v(k-1), v(k-2), y(k-1), y(k-2), y(k-3)\right)
$$

したがって，式(38)および式(39)より NNの出力 $u_{N}(k)$ はつぎのようになる. 


$$
\begin{aligned}
u_{N}(k) & =v(k)-u(k) \\
& =h_{f}\left(u(k), y_{M}(k+2), v(k-1), v(k-2), y(k-1), y(k-2), y(k-3)\right)
\end{aligned}
$$

結局, NN の目的は(39)式右辺の非線形関数を実現することにある.このため, $h_{f}(\bullet) の(\bullet)$ 内の変数が NNの入 力変数として最低限必要である. また， NNの学習は，プラントと規範モデル間の出力誤差 $e(k)=y(k)-y_{M}(k)$ を零 にするようにNNの重みを調整することによって行われる.

ここで用いる NNは, 図 4 に示す 3 層の階層型とし, 入力層の 7 個のユニット $x_{i}(k)(i=1 \sim 7)$ はつぎのようにした.

$$
\left\{x_{i}(k)\right\} \equiv\left\{u(k), y_{M}(k+2), v(k-1), v(k-2), y(k-1), y(k-2), y(k-3)\right\} \quad(i=1 \sim 7)
$$

中間層には 13 個のユニット $h_{j}(k)(j=1 \sim 13)$ を設け, 出力層は $u_{N}(k)$ のみである.

このとき，式(40)の右辺はつぎのように表現できる.

$$
\begin{aligned}
& u_{N}(k)=\sum_{j=1}^{13} w_{j}^{(2)}(k) h_{j}(k) \\
& h_{j}(k)=f\left(\sum_{i=1}^{7} x_{i}(k) w_{i j}^{(1)}(k)\right)
\end{aligned}
$$

ただし，

$$
f(x)=\frac{1}{1+\exp (-x)}
$$

$\mathrm{NN}$ の学習は, バックプロパゲーション $(\mathrm{B} \mathrm{P})$ 法により, 入力層から中間層への重み $w_{i j}^{(1)}(i=1 \sim 7, j=1 \sim 13)$ と中 間層から出力層への重み $w_{j}^{(2)}(j=1 \sim 13)$ をプラント出力 $y(k)$ と規範モデルの出力 $y_{M}(k)$ の二乗誤差が最小になるよ うに調整することによって行われる，すなわち，それぞれの重みはつぎのように更新される.

$$
\begin{aligned}
& w_{i j}^{(1)}(k+1)=w_{i j}^{(1)}(k)-\eta\left(y(k)-y_{M}(k)\right) \frac{\partial y(k)}{\partial v(k-2)} w_{j}^{(2)}(k-2) h_{j}(k-2)\left(1-h_{j}(k-2)\right) x_{i}(k-2) \\
& w_{j}^{(2)}(k+1)=w_{j}^{(2)}(k)-\eta\left(y(k)-y_{M}(k)\right) \frac{\partial y(k)}{\partial v(k-2)} h_{j}(k-2)
\end{aligned}
$$

ここで, $\eta$ は学習率で正の定数である. 上式の計算では, プラント出力の微分情報すなわち $\partial y(k) / \partial v(k-2)$ が必要 となるが, 学習を行う NN 自身の状態と MRAC のプラントのパラメータ推定值を用いてつぎのように微分係数が 簡単に計算できる(辻他, 1994).

$$
\frac{\partial y(k)}{\partial v(k-2)}=\hat{b}_{0}(k) /\left\{1+\sum_{j=1}^{13} w_{j}^{(2)}(k-2) h_{j}(k-2)\left(1-h_{j}(k-2)\right) w_{1 j}^{(1)}(k-2)\right\}
$$

このように，NN の学習はNN 自身の状態と MRAC のプラントのパラメータ推定值を用いることで，簡単かつ 素早く計算できるため MRAC と併用することに適していると考えられるが，一方では MRAC で同定を行ったプ ラントパラメータを用いることから, MRAC 自身も外乱に対する頑強性をもっていなければならないことがわか る. 本論文で提案する構成法においては，前章の(25)式で示したようにMRAC の同定機構において，外乱を考慮 した構成法を用いていることから, MRAC の制御性能を向上させただけでなく, NN の学習性能も向上させてい ることがわかる。 


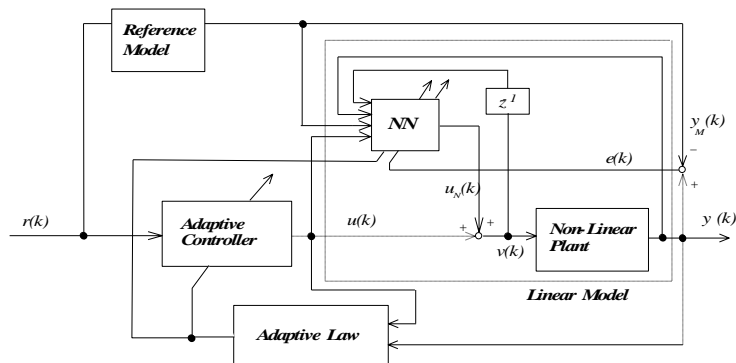

Fig.3 Schematic diagram of MRAC with NN. The role of the $\mathrm{NN}$ is to linearize the non-linear plant and to produce the linearized model of it.

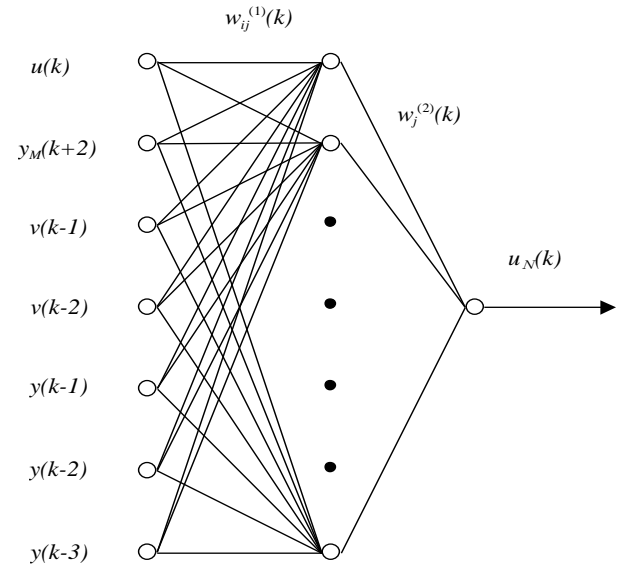

Fig.4 Construction of the 3-layers type Neural Network. The input-layer consists of 7 units, the hidden-layer contains 13 units and the output-layer is only the output.

\section{5. 実験結果}

\section{$5 \cdot 1$ NN を併用したモデル規範型適応制御の適用}

本構成法の有用性を確認するため, 実在の空気圧サーボ系による実験を行った. 規範モデルには, 減衰比 $\zeta=2$, 固有振動数 $\omega_{n}=20,[\mathrm{rad} / \mathrm{sec}]$ の連続時間 2 次系を離散化したものを用いた. MRAC で用いた各パラメータはつぎの ようなものである.

$$
\begin{aligned}
& a_{M 1}=-1.329, a_{M 2}=0.368, \Gamma(0)=1 \times I \\
& b_{M 0}=0.023, b_{M 1}=0.016, \delta=0.025 \\
& a_{1}(0)=1.17, a_{2}(0)=-0.47, a_{3}(0)=0.3, \\
& b_{0}(0)=-0.7, b_{1}(0)=-0.52, b_{2}(0)=-0.14
\end{aligned}
$$

物体とピストンロッドの間に設置したばねには, 最初はばね定数 $\mathrm{K}$ を $3[\mathrm{~N} / \mathrm{mm}]$ とした物を用いて実験を行った。 まず外乱補償のない従来の MRAC のみの構成法および本研究で提案する構成法により，目標值を $5[\mathrm{~N}]$ とした場 合の過渡状態における実験結果を示す．図 5 は従来の構成法の実験結果，図 6 は本研究で提案する実験結果を示 している. また図 5(a)はプラントの出力 $y(k)$ と規範モデルの出力 $y_{M}(k)$ を対比して示しており，図 5(b)は制御入力 $u(k)$, 図 5(c) はプラントの推定パラメータを示している. 図 5 より出力は制御開始直後に乱れるが，徐々に一定 值に落ちつくと同時に，パラメータの同定值も収束に向かっており，適応機構が正常に動作していることが分か る. しかし, 出力に定常偏差とみられる誤差や出力が安定した後もパラメータの変動が長く続くなど十分な制御 性能を得られていないと考えられる。これに対し，図6(a)より本研究で提案する構成法では，制御開始直後は出 力が大きく乱れているがパラメータの同定後はプラントの出力 $y(k)$ は目標值に一致しており, 良好な制御性能の 得られていることがわかる. しかし, 従来の MRAC の実験結果と比べて出力が大きく乱れるため, 出力が規範モ デルに近づく時間が少し遅れていることが確認できる。これは NN がプラントの推定パラメータを用いて学習を 行っているため，プラントパラメータの推定值が乱れている状態では正しい学習は行われず，未学習に近いNN の出力がプラントに加わるためであると考えられる，このことは，図 6(b) および図 6(c)より，プラントパラメー タの推定值が振動している状態において NN の出力が大きく負の方向に出力されるが，パラメータが安定してく ると NN の出力も小さくなっていることから推測される，すなわち，本研究で提案する構成法では，MRAC の同 
定機構においてプラントパラメータの推定值を素早く正確に求める等の改善がなされており，過渡応答における NN の悪影響を小さく抑えていると考えることができる.

つぎに目標值を矩形波状 $(r(k)=2.5[\mathrm{~N}]$ および $r(k)=7.5[\mathrm{~N}])$ に与えた場合の定常応答における実験結果を示す. 図 7 は外乱補償のない従来の MRACにNN を併用した構成法, 図 8 は本研究で提案する構成法, すなわち改善さ れた MRACにNNを併用した構成法による実験結果を示している. 前述の実験結果から, 外乱補償のない従来の MRAC を用いた構成法ではパラメータの推定に時間がかかることがわかったため, 従来の MRACにNNを併用 する場合には，MRAC の出力が落ち着いた後，NN の併用を行うこととした．図７より，従来の MRACに NNを 併用した構成法により目標值が変化した場合にもプラントの出力 $y(k)$ は規範モデルの出力 $y_{M}(k)$ に追従できてい ることがわかる. しかし, プラントのパラメータが真值に収束しないため, 出力 $y(k)$ と規範モデル $y_{M}(k)$ の間に 若干のずれが生じるだけでなく, プラントパラメータが絶えず変動を起こしている. これに対し, 図 8 より, 本 研究で提案する構成法では, 出力 $y(k)$ と規範モデルの出力 $y_{M}(k)$ がほぼ完全に一致し, プラントパラメータの推 定值も目標值のステップごとに一定の值を保っていることがわかる.

これらの実験結果より, 本研究で提案する構成法では, 過渡状態及び定常状態において適応機構が良好に動作 し，制御目的が達成されていることがわかった．また，従来の MRAC 等との比較を行うことにより，本構成法に おける従来の構成法からの改善点に対する有効性も確認された.

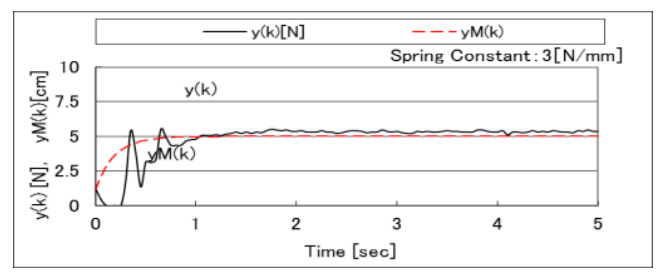

(a) Plant output $y(k)$ and reference input $y_{M}(k)$

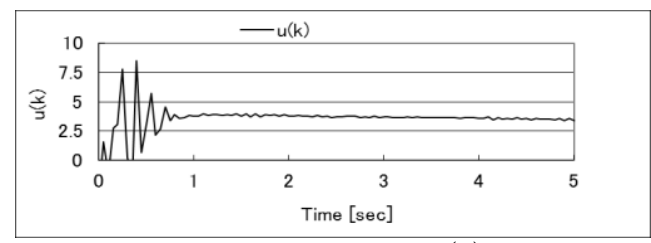

(b) Control input $u(k)$

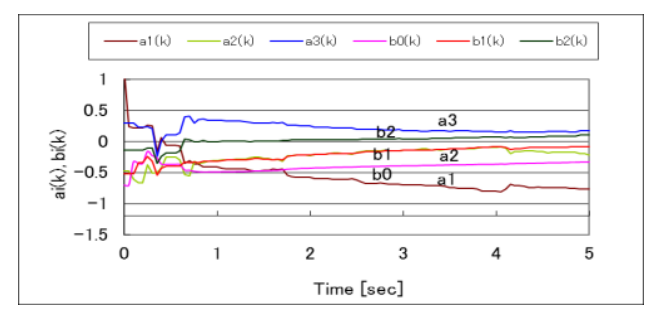

(c) Identified parameters $\hat{a}_{i}(k), \hat{b}_{i}(k)$

Fig.5 Transient Responses of conventional MRAC. Output has a steady-state error.

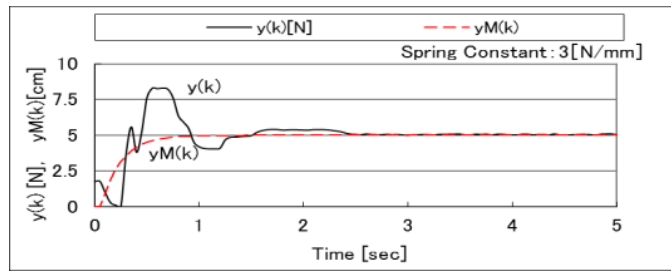

(a) Plant output $y(k)$ and reference input $y_{M}(k)$

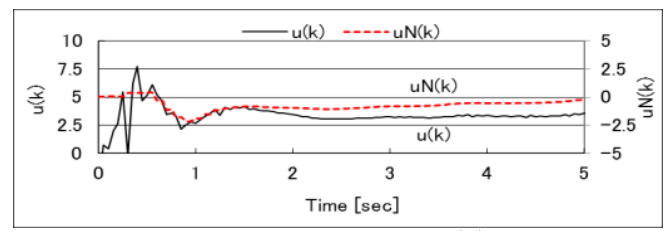

(b) Control input $u(k)$

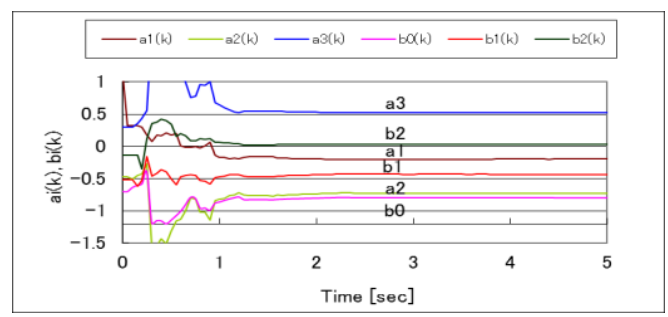

(c) Identified parameters $\hat{a}_{i}(k), \hat{b}_{i}(k)$

Fig.6 Transient Responses of proposed scheme. It is gradually stabilized to the plant output and identified parameters vary. Then, adaptive identifier works well. 


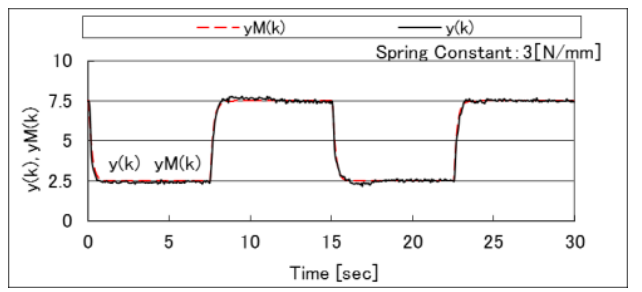

(a) Plant output $y(k)$ and reference input $y_{M}(k)$

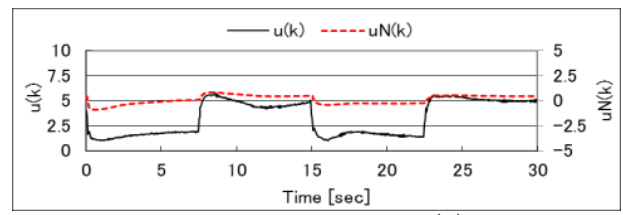

(b) Control input $u(k)$

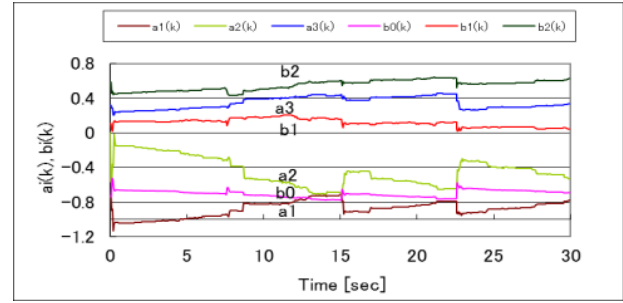

(c) Identified parameters $\hat{a}_{i}(k), \hat{b}_{i}(k)$

Fig.7 Steady State Responses of conventional MRAC with NN. The plant output narrowly tracks to the output of the reference model.

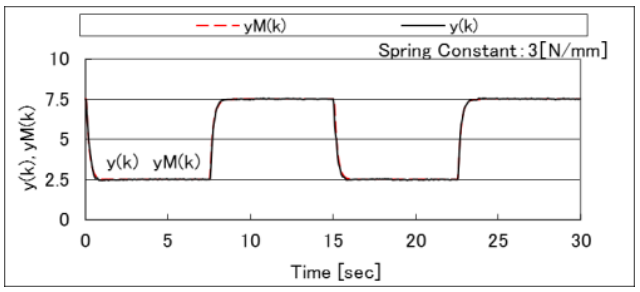

(a) Plant output $y(k)$ and reference input $y_{M}(k)$

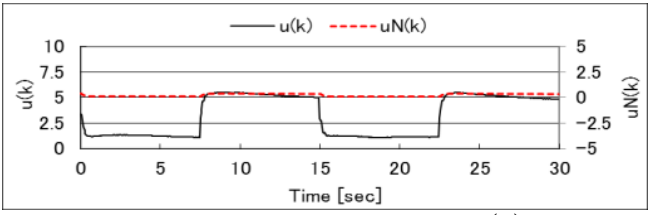

(b)

Control input $u(k)$

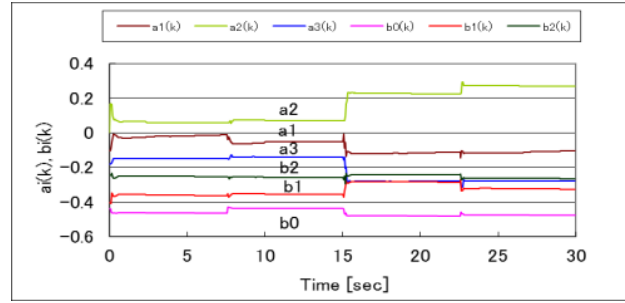

(c) Identified parameters $\hat{a}_{i}(k), \hat{b}_{i}(k)$

Fig.8 Steady State Responses of proposed scheme. The plant output tracks to the output of the reference model very well.

\section{$5 \cdot 2$ 物体が移動する場合}

力を及ぼす対象となる物体が動くとピストンが物体により押し込まれることとなり力制御系には大きな外乱が 加わることが予測される。そこで物体を正弦波状に移動させた時のピストンロッド先端に加わる力を測定する実 験を行った.

はじめにシリンダに一定の圧力差（5[N]を発生させる入力）を加えている状態で物体を移動させた場合，すな わちシリンダから発生する力を一定に保つために制御バルブにはコンピュータからの入力は変化させず，シリン ダ内の圧力のみがバルブにより一定に保たれるように設定した状態で，物体を左右に移動させている．実際に実 験を行った結果を図 9 に示す。台車の位置 $x(k)$ は, 台車と物体が接触する位置をほぼ 0 とし, ピストンが物体に 近づく方向がプラスとなるように表示している． $x(k)$ が増加しているとき，すなわち物体がシリンダから離れる 方向に移動しているときには力の変化はないが，物体がシリンダに近づくときには一定の力（2[N]程度）が加わ り, 出力 $y(k)$ が矩形波状に変化していることが分かる. また，このときシリンダ室内の圧力 $P_{l}(k), P_{2}(k)$ は変化し ていないことが分かる。すなわち，この図よりシリンダ室内の圧力変化が無いにもかかわらず，力センサからの 信号は鋸状に変化していることが分かる．この力の変化する周期はピストンの移動する周期と一致しており，物 体がピストンを押しているときには外乱となる力を生じており, 逆にピストンから離れていく方向には力が生じ ていない，したがって，この外乱はクーロン摩擦のように一定值ではあるが，移動方向に依存した非線形な力が 外乱として力制御系に作用していると考えられる. 本研究で提案する構成法では，MRACにおいては，このような 外乱に対する耐性を持たせるだけでなく, 内部信号の改質によりプラントパラメータの正確性が保障されている ことから，NNの併用が可能であり，その有用性を検証する実験方法として適していると考えた。また，PID制御 
を用いるに当たり，PID の各パラメータは限界感度法により推定される值を基準とし，MRACでの実験結果を考え 合わせて調整した結果，つぎのように定めた。

$$
K_{P}=0.6, \quad K_{I}=0.2, \quad K_{D}=0.45
$$

図 10 に PID 制御，図 11 に本研究で提案する NNを併用した MRAC による構成法を用いて実験を行った結果を示 寸.これらの図よりPID 制御および本構成法，ともにプラントの出力 $y(k)$ は物体が動きの向きを変えた瞬間 に摩擦力が大きく変化するために出力は一時的に乱れるが，すぐに目標值 $r(k)$ または規範入力 $y_{\mu}(k)$ とほぼ一 致して良好に制御されていることがわかる。

以上の実験結果から本構成法により力を加える対象の物体が動いている場合でも最適にパラメータ調整された PID 制御と同程度に一定の力を制御することが可能であることが分かった.

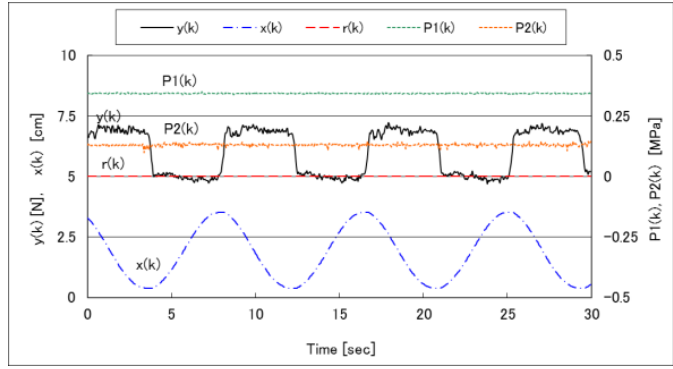

Fig.9 Result of preliminary experiment.It is shown that an external force caused by an object moving arise without a pressure change.

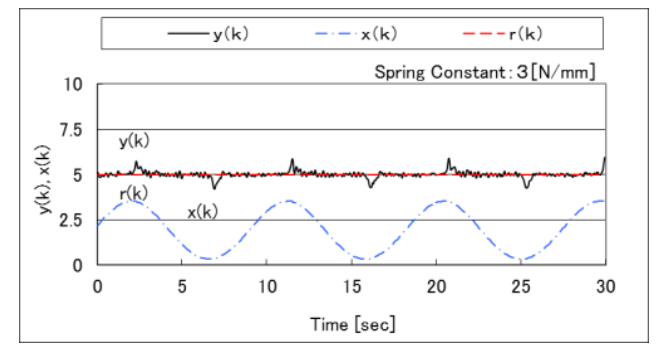

Fig.10 Result of an experimentwithPID.It seems that the PID controller can be appropriately controlled in this condition.

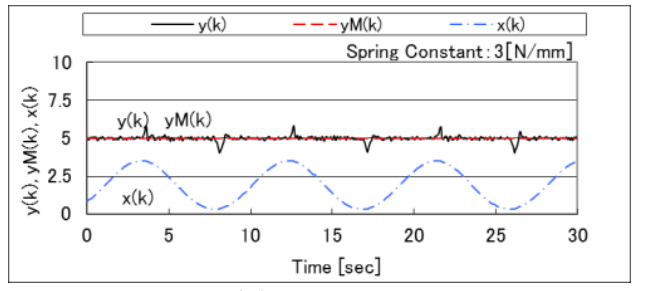

(a) Plant output $y(k)$ and reference input $y_{M}(k)$

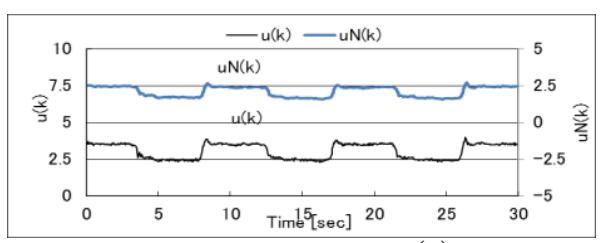

(b) Control input $u(k)$

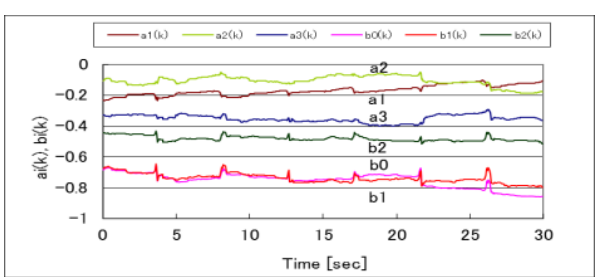

(c) Identified parameters $\hat{a}_{i}(k), \hat{b}_{i}(k)$

Fig.11 Result of an experimentwith MRAC. These results and a comparison with PID show that the proposed design scheme has the same control performance under this

\section{$5 \cdot 3$ 物体の剛性が変化した場合}

つぎに物体の硬さが変化した場合を想定して柔らかいばねおよび硬いばねを用いた場合，すなわち，ばね定数 が $2[\mathrm{~N} / \mathrm{mm}]$ および $6[\mathrm{~N} / \mathrm{mm}]$ のばねを用いて実験を行った．PID の各ゲインは(49)式の值をそのまま用いた．図 12 にPID 制御を用いた場合. 図 13 に本構成法を用いて実験を行った場合の結果を示す. 図 12 (a) は, ばね定数が $2[\mathrm{~N} /$ mm] として実験を行った結果を示しており, 図 12 (b) は6[N/mm]の場合を示している. 図 12 より, PID 制御では, 応答が振動的になり PID のパラメータを再調整する必要のあることが分かる. また, 図 12 (a)においてはピスト ンが激しく振動を起こし, 制御性能が著しく低下した状態となっている. 図 10 の結果と考え合わせるとPID 制御 
のような固定ゲインによる方法では物体の硬さが変化した場合，制御性能が劣化するだけで無く，制御不能に陥 る危険性もあることが分かる．才なわち，物体が動く場合には，ばね定数が $3[\mathrm{~N} / \mathrm{mm}]$ から $2[\mathrm{~N} / \mathrm{mm}]$, 又は $3[\mathrm{~N} / \mathrm{mm}]$ から $6[\mathrm{~N} / \mathrm{mm}]$ の変化をさせるという設定で十分大きなプラントの特性変化が生じていることが分かる. これに対 し，本構成法では図 11 と図 13 の結果から物体の固さが変化した場合でも良好な制御性能が維持されていること が分かる．すなわち，今回の実験で用いた物体の硬さは PID 制御であればパラメータの再調整が必要なほど変化 しているが，本構成法では再調整の必要がなく，有用性が示された.

以上の実験結果から, 硬さの違う物体に対しても本構成法の適用が可能であることが分かった．また，PID 制 御と比較することにより本構成法の有用性も確認された.

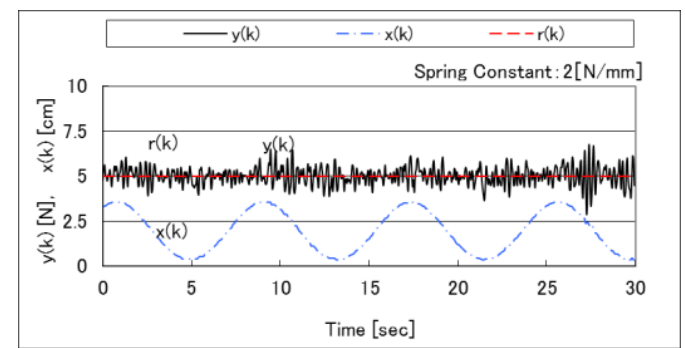

(a) Spring constant $\mathrm{K}=2$.

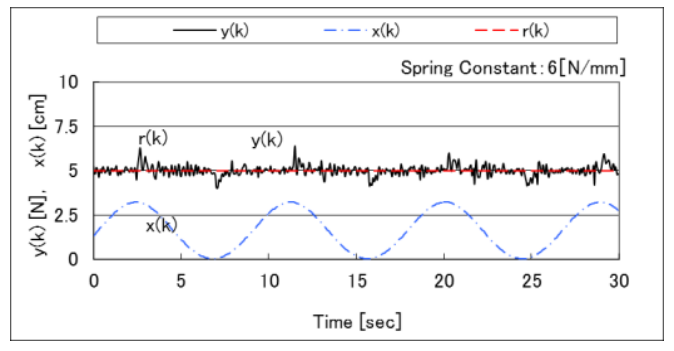

(b) Spring constant $\mathrm{K}=6$.

Fig.12 Result of an experiment with PID in the case of changing spring constant. It is difficult to accomplish the satisfactory control performance by using PID under thesecondition.

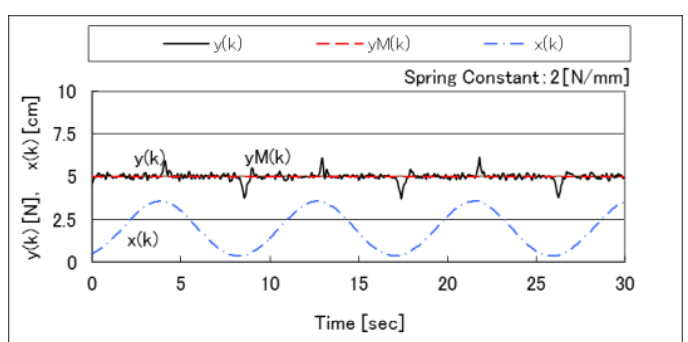

(a) Spring constant $\mathrm{K}=2$.

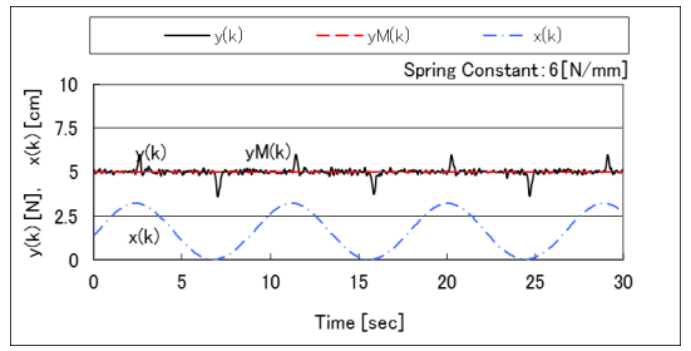

(b) Spring constant $\mathrm{K}=6$.

Fig.13 Result of an experiment with MRAC in the case of changing spring constant . These results from experiments and a comparison with PID control show a robustness of the controller under the environmental change.

\section{6. 結 言}

本研究では空気圧シリンダを用いて動く物体に対する力制御系における NNを併用したMRAC の一構成法を提 案した。本構成法では，MRACの内部信号を改善するだけでなく，空気圧サーボ系に本質的に含まれる非線形の 影響を考慮して，NNを併用した．また，制御系の内部信号の改質により，MRAC の性能を向上させるだけでな く, NN の学習性能を改善させた。 また，実機実験では，さまざまな硬さの物体に対して本構成法による NN 併 用型 MRAC の適用が可能であることが分かった. また，力を及ぼす物体が動いている場合においてもほぼ一定の 力を制御することが可能であることを示し，本構成法の有用性を確認した.

\section{文献}

則次俊郎,和田力,伴野順一, 電空制御弁の動作遅れを考慮した空気圧サーボ系の最適制御, 計測自動制御学会論文

集，Vol.24, No.5 (1988a)，pp.490-497.

則次俊郎, 和田力, 矢野坂雅巳, 空気圧サーボ系の適応制御, 計測自動制御学会論文集, Vol.24, No.11(1988b), 
pp.1187-1194.

則次俊郎,和田力,西口登，適応制御を用いた空気圧サーボ系の力制御，計測自動制御学会論文集，Vol.26(1990), pp.196-203.

坂田浩一,田中幹也,清水顯, 空気圧サーボ系における適応極配置制御, 日本機械学会論文集 C 編, Vol.59, No.565(1993), pp.2712-2717.

辻純一,大森浩充,佐野昭，ニューラルネットワークを併用した適応制御，計測自動制御学会論文集，Vol.30, No.3 (1994), pp.295-302.

内山直樹, 江崎昇二, 高木章二, 離散時間適応サーボ系の一設計法とその空気圧サーボ系への応用，日本機械学 会論文集 C編，Vol.69 (2003),pp.55-62.

山藤和男,小林義武,石橋昌宏, 空気圧シリンダの最適制御, 日本機械学会論文集 C編, Vol.53, No.487(1987), pp.757-762 .

\section{References}

Noritsugu, T., Wada, T. and Tomono, J., Design of optimal pneumatic Servo system considering control valve delay time, Transactions of the Society of Instrument and Control Engineers,Vol.24, No.5 (1988a), pp.490-497 (in Japanese).

Noritsugu, T., Wada, T. and Yanosaka, M., Adaptive control of a pneumatic servo system, Transactions of the Society of Instrument and Control Engineers, Vol.24, No.11 (1988b), pp.1187-1194 (in Japanese).

Noritsugu, T., Wada, T. and Nishiguchi, N., Force control of a pneumatic servo system with adaptive control, Transactions of the Society of Instrument and Control Engineers, Vol.26 (1990), pp.196-203 (in Japanese).

Sakata, K., Tanaka, K. and Shimizu, A., Adaptive pole-placement control for pneumatic servo systems, Transactions of the Japan Society of Mechanical Engineers, Series C, Vol.59, No.565 (1993), pp.2712-2717(in Japanese).

Tsuji, J., Ohmori, H. and Sano, A., Adaptive control incorporating neural network, Transactions of the Society of Instrument and Control Engineers, Vol.30, No.3 (1994), pp.295-302 (in Japanese).

Uchiyama, N., Esaki, S. and Takagi, S., A Design of discrete-time adaptive servo system and Its application to a pneumatic servo system, Transactions of the Japan Society of Mechanical Engineers, Series C, Vol.69 (2003), pp.55-62(in Japanese).

Yamafuji, K., Kobayashi, Y. and Ishibashi, M., Optimal control of a pneumatic cylinder, Transactions of the Japan Society of Mechanical Engineers, Series C, Vol.53, No.487 (1987), pp.757-762 (in Japanese). 